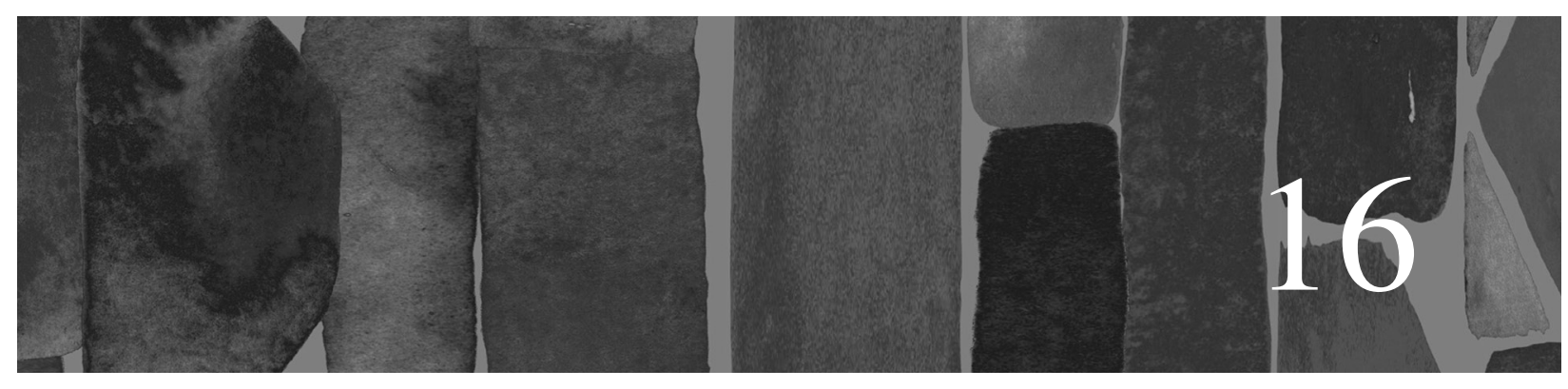

\title{
Exploring Electronic HRM: Management Fashion or Fad?
}

Tanya Bondarouk, Huub Ruël and Bram Roeleveld

\section{INTRODUCTION}

At the end of the 1990s and in the early 2000s organisations started to adopt electronic human resource management (e-HRM). This was motivated by assurances that it would reduce paperwork, make HR processes more efficient, improve HR's service quality and allow HR to become a more strategic business partner. HR and IT scholars quickly 'jumped on' the 'e-HRM train'. They questioned these promises and sought to provide more solid insights on e-HRM implementation, adoption and its impact. Defining e-HRM did not seem to be that easy, as many definitions have been proposed in scholarly work. Today, the most cited definition of e-HRM describes it as either a set of information technology (IT) applications that cover 'all possible integration mechanisms and contents between HRM and is aiming at creating value within and across organisations for targeted employees and management' (Bondarouk \& Ruël, 2009, p. 507), or 'the planning, implementation and application of IT for both networking and supporting at least two individual or collective actors in their shared performing of HR activities' (Strohmeier, 2007, p. 20).

Today, the accumulated scholarly literature on e-HRM has provided findings on whether e-HRM reduces the administrative burden under certain circumstances, improves HRM service quality and improves HR's strategic orientation (Bondarouk \& Ruël, 2013). A still growing group of e-HRM scholars also have researched the changing role of the HR function towards becoming a business partner, for example using HR metrics for strategic decision-making (Hendrickson, 2003) and the empowerment of managers through the development and support of management capacity to conduct HR activities (Parry \& Tyson, 2011). Some studies show that e-HRM increases the time available for strategic HR issues (such as strategic people management activities) because of the automation of routine HR tasks (Bondarouk \& Ruël, 2013; 
Martin, Reddington, \& Alexander, 2008). Due to the automation of HR tasks, HR professionals have been transformed from administrative paper handlers to strategic partners (Voermans \& Van Veldhoven, 2007). E-HRM research also can facilitate improved talent management through e-selection, self-assessment and e-performance management (Martin et al., 2008). This will help to address the four major global talent management challenges (e.g. right numbers, right location, right competencies and motivation, right price) as identified by Schuler, Jackson and Tarique (2011). Finally, research provides insights on how e-HRM can contribute to employer brands and improve an organisation's image (Bondarouk \& Ruël, 2013).

However, two decades after e-HRM started to be adopted by private and public sector organisations, it is still unclear whether e-HRM should be considered to be an innovation or as a hype that basically has no 'substance'. The questions that remain for e-HRM to investigate are whether organisations are driven by rationales (as is presumed), or mostly by the fact that their peers and competitors are adopting it, and whether factors influence the decision-making processes to adopt e-HRM or not. The aim of this study is to investigate to what extent e-HRM as a management technique can be considered a management fashion. It first explores the theory of management fashion introduced by Abrahamson (1996). Then it applies this theory to e-HRM and provides a set of case studies. The results are then reflected upon in a discussion section. Finally, the chapter ends with a set of conclusions.

\section{THEORY OF MANAGEMENT FASHION}

In 1996, Eric Abrahamson published an article about management fashion in the Academy of Management Review in which he presented the idea that fashion (just like modes, vogues, rages and crazes) frequently revolutionises many aspects of cultural life (Abrahamson,
1996). Since this publication of a theory of management fashion, there has been profound interest in the observation that management ideas and techniques are 'subject to swings in fashion in the same way as aesthetic aspects of life' (Clark, 2004, p. 297). A management fashion is viewed as a transitory collective belief, disseminated by management fashion setters, where a certain management technique leads rational management progress. It can differ in scope and in duration. In the model of Abrahamson (1996), groups of interrelated knowledge owners and entrepreneurs (consultants, gurus, business schools, mass media) are racing to sense the collective preferences for new tools and techniques by managers. They develop rhetoric to convince fashion followers about the progressive sustainable new technique (e.g. 'Learning Organization', Senge in 1990; 'War for Talent', McKinsey in 1997; 'New Ways of Work', Microsoft in 2003; 'Agile Working' in 2001; 'Big Data' and 'HR Analytics' since the last decade ). It is important to understand that management fashion setters constantly redefine their own, as well as their followers', beliefs about which techniques lead to this progress. They deliberately produce management fashions in order to market them to fashion followers (Abrahamson, 1996). Therefore, their rhetoric must 'articulate why it is imperative that managers should pursue certain organisational goals and why their particular technique offers the best means to achieve these goals' (Clark, 2004, p. 298). In his earlier work, Abrahamson (1991) argued that fashion setters sometimes promote innovations that are already adopted by certain organisations (most of the time these are technically efficient innovations) and try to sell them to those organisations that have not adopted them.

Clark (2004) elaborated on the different types of management fashion setters by distinguishing between management gurus, management consultants, business schools, academics and publishers. Management gurus create innovative, popular, strategic 
ideas by publishing best-selling books, articles in leading business journals or talks on the international lecture circuit. Management consultants include significant producers and consumers of management knowledge. They often position themselves as 'thought leaders' by actively creating in-house gurus. Usually they would have experience with clients and have adequate research capabilities within their firms. Business schools and management academics play a double role through representing important consumers, as well as producers of management ideas. Publishers are concerned with identifying, producing and distributing ideas that are likely to have mass appeal (Clark, 2004).

The management literature has known peaks of activity, for example when management fashion itself was a fashionable area of academic enquiry (i.e. special issues of the Journal of Management History, 1999, and in Organization, 2001). One reason for the scholarly preoccupation with management fashion was concerned with whether academic knowledge was developing independently from fashion setters, what the status of academic discovery was in management, and what its explanatory and predictive power was. There were probably other hidden reasons for the great interest in management fashion - for example, scholars' desire to understand the success and impact of fashion setters, and an intrinsic motivation to produce valuable and actionable knowledge, as 'the fashionable is never authentic or robust, but always untrustworthy, unpredictable, fickle and capricious' (Ten Bos, 2000, p. 5). However, this chapter is not concerned with a critique of management fashion or with the nature of fashionable knowledge. Instead, we try to understand e-HRM, the subject of our investigation, from a management fashion perspective.

The first articles on e-HRM (then, HR information systems) date back to the 1970s (for an overview of four decades of e-HRM research, see Bondarouk, Parry, \& Furtmuller, 2017). Abrahamson argues that socio-psychological and techno-economic forces compete in shaping the demand for a particular management fashion. Both are external factors and can consist of, for example, globalisation, environmental changes and customer preferences (Abrahamson, 1996). Which forces prevail depends, in part, on whether and how management scholars intervene in the fashion-setting process (Abrahamson, 1996, p. 271).

Socio-psychological factors originate from human desires and may consist of psychological states, such as boredom, striving for individuality and novelty (compared to the mass, who are 'out of fashion'), frustration and striving for status differentiation (Abrahamson, 1996). Frustrations and despair leave managers vulnerable to unrealistic hopes that, by using another management technique, this will magically relieve them from pressure. As Abrahamson and Fairchild (1999) pointed out, emotionally charged, enthusiastic and unreasoned discourse characterises the upswings in management fashion waves, whereas reasoned, unemotional and qualified discourse characterises their downswings. This evidences a pattern of superstitious collective learning according to Abrahamson and Fairchild (1999, p. 709). Abrahamson and Fombrun (1994) call the process of status differentiation a trickle-down fashion process. Lower status organisations can adopt fashionable techniques to make their organisations look like higher status organisations. This, in turn, puts pressure on higher status organisations to distinguish them again (Abrahamson, 1996).

Techno-economic forces include macroeconomic fluctuations, political forces and contradictions originating from within organisations. These forces open up gaps between an organisation's actual and desired performance (desired state). The management fashion-setting process brings these performance gaps to the collective awareness and articulates new, progressive and collectively acceptable techniques for narrowing these gaps. This does not mean the gaps can be measured easily. Neither can they be solved by technically efficient management techniques 
straight away. Techno-economic changes create preferences among fashion followers. Based on these preferences, fashion setters will shape demand for management techniques (Abrahamson, 1996). Fashion setters will not only shape the demand for management fashions (based on norms of rationality and progress), but also sense the demand for management techniques based on sociopsychological and techno-economic forces (Abrahamson, 1996, p. 267). Finally, some fashions can achieve widespread adoption and continued use for a considerable period of time. On the other hand, some fashions will decline quickly. These fashions can be considered as 'fads' (Grant, 2011, p. 118). Also, in a period of decline (within a certain subject area), a redefinition will take place. In this case, fashion setters can introduce innovation (Grant, 2011).

\section{APPLICATION OF MANAGEMENT FASHION THEORY TO E-HRM}

Table 16.1 provides an overview of some HRM studies showing those that have applied management fashion theory, the goal the researchers tried to achieve by their studies, which methods they used to study the phenomenon, and their findings. It becomes clear that Abrahamson's theory has a number of limitations. For example, constructs are often characterised by conceptual ambiguity. To increase the change of gaining popularity, fashion setters should try to keep their 'product' ambiguous to a certain degree. This tactic means that a fashion can be interpreted in different ways by different actors, each demanding a solution for their problems (i.e. performance gaps). This is called 'interpretative viability' by Benders and van Veen (2001) - originally a term of Ortmann (1995). Buyers of management fashions may recognise their own situation in the rhetoric used to sell management fashion and, thereby, increase the potential market for a management fashion. e-HRM buyers can select those elements that appeal to them and that they believe are suitable for their purposes. The fashion can also unite different parties because each party is in favour of the concept to further their own particular interests (Benders \& Van Veen, 2001).

What do the different researchers in Table 16.1 add to management fashion theory? Madsen and Slåtten (2015) added social media as a management fashion setter, not only as a supplier of ideas, but also as a consumer. They argued that social media were a totally different actor than print media, because of their 'networking' capabilities. Grant (2011) named different kinds of gurus: not only the management gurus that Abrahamson (1996) mentioned, but also academic gurus, hero manager gurus and consultant gurus. Fincham and Roslender (2004) argued that the process of dissemination of management fashions can also be a function of internal controls and operational constraints, instead of always coming from outside an organisation. Madsen and Slåtten (2013) took the cross-national component of the diffusion of management fashions into account, which, according to them, are subject to countryspecific configurations. Finally, Wang (2010) argued that firms adopting management fashions, in general, had a better reputation and paid their executives better, but even this did not necessarily lead to better performance. Based on the analysis of different studies that used Abrahamson's (1996) framework, we adjust the model of management fashion theory to e-HRM studies (see Table 16.2 and Figure 16.1).

\section{E-HRM AS MANAGEMENT FASHION: CASE STUDIES}

We now turn to the analysis of case studies about e-HRM implementation reported in academic articles (Table 16.3) to investigate to what extent e-HRM can be considered a management fashion (or a fad). 


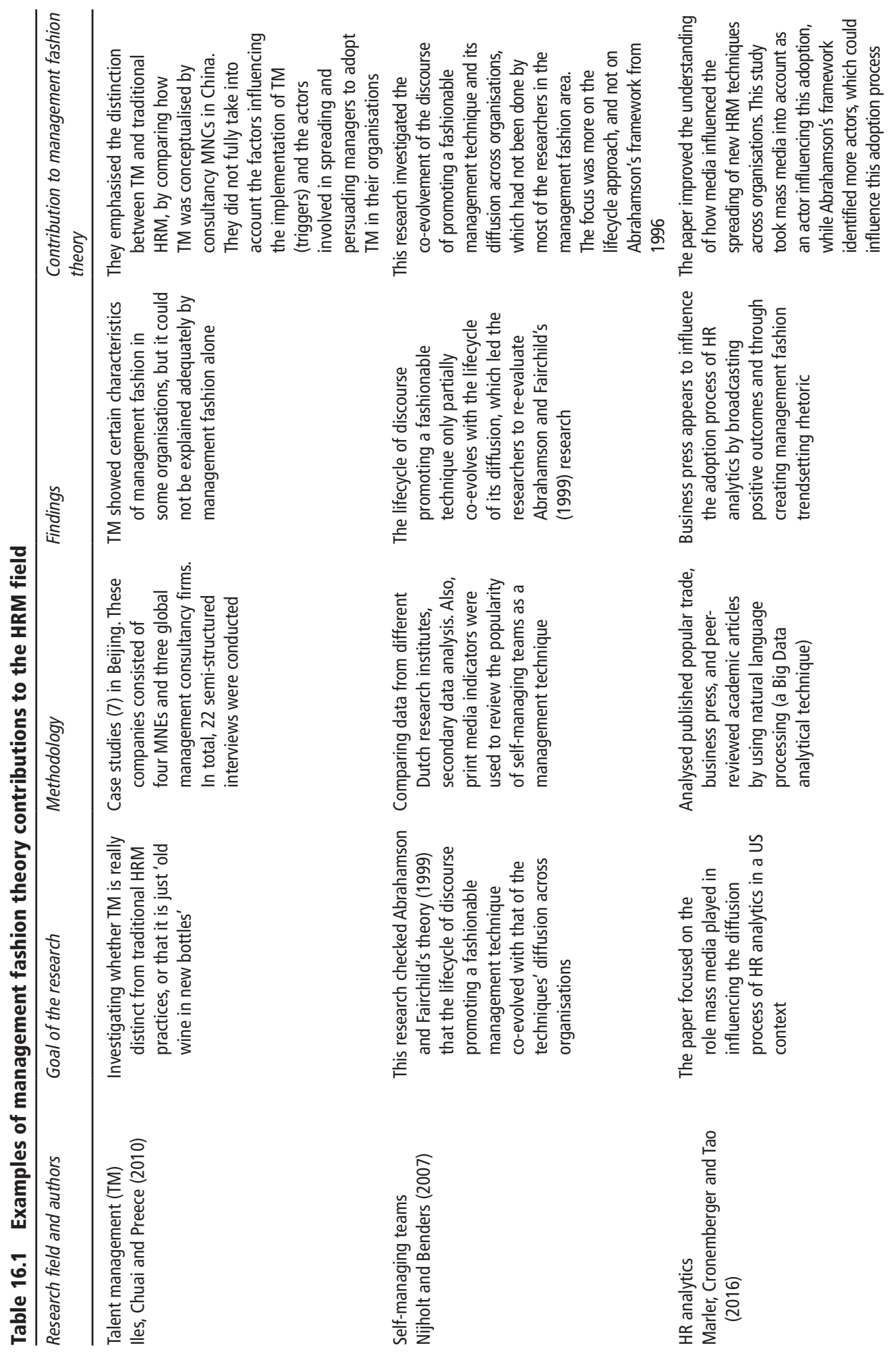




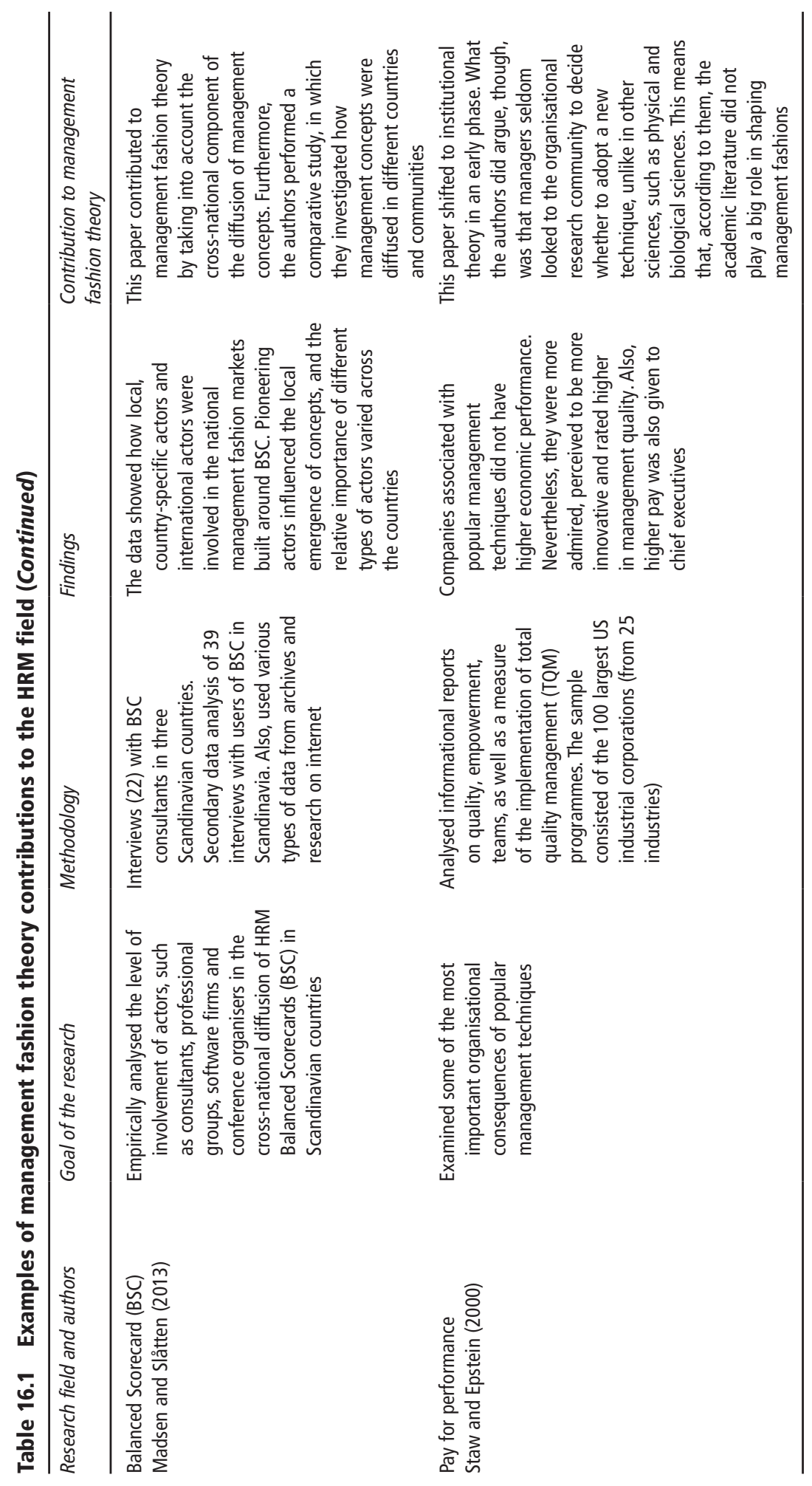


Table 16.2 Definitions of the constructs

\begin{tabular}{lc}
\hline Concept & Operational definition \\
\hline Norms of rationality and progress & $\begin{array}{c}\text { Society-forced expectations that managers have to use management } \\
\text { techniques that are believed to be new, improved and the most } \\
\text { efficient } \\
\text { The processing and dissemination of rhetoric by fashion setters that can } \\
\text { convince potential e-HRM users to use this management technique } \\
\text { Launching of e-HRM }\end{array}$ \\
$\begin{array}{l}\text { The volume of rhetoric the management fashion provides to the e-HRM } \\
\text { market }\end{array}$ \\
Demand by e-HRM users & $\begin{array}{c}\text { The explicit willingness of organisations to buy e-HRM services for a } \\
\text { certain price }\end{array}$ \\
Sensing of e-HRM demand by fashion setters & $\begin{array}{c}\text { The selection and creation of the e-HRM fashion by the fashion-setting } \\
\text { community, based on the demand by potential e-HRM users }\end{array}$ \\
Socio-psychological and techno-economic forces & $\begin{array}{c}\text { Forces based on people's desires (socio-psychological), macro-economic } \\
\text { fluctuations, politics and contradictions within organisations } \\
\text { (techno-economic) }\end{array}$ \\
Country-specific configurations & $\begin{array}{c}\text { Local actors and institutions that influence the adoption and } \\
\text { implementation of e-HRM within organisations } \\
\text { Internal forces that compete to shape the demand for e-HRM within } \\
\text { organisations }\end{array}$ \\
\hline
\end{tabular}

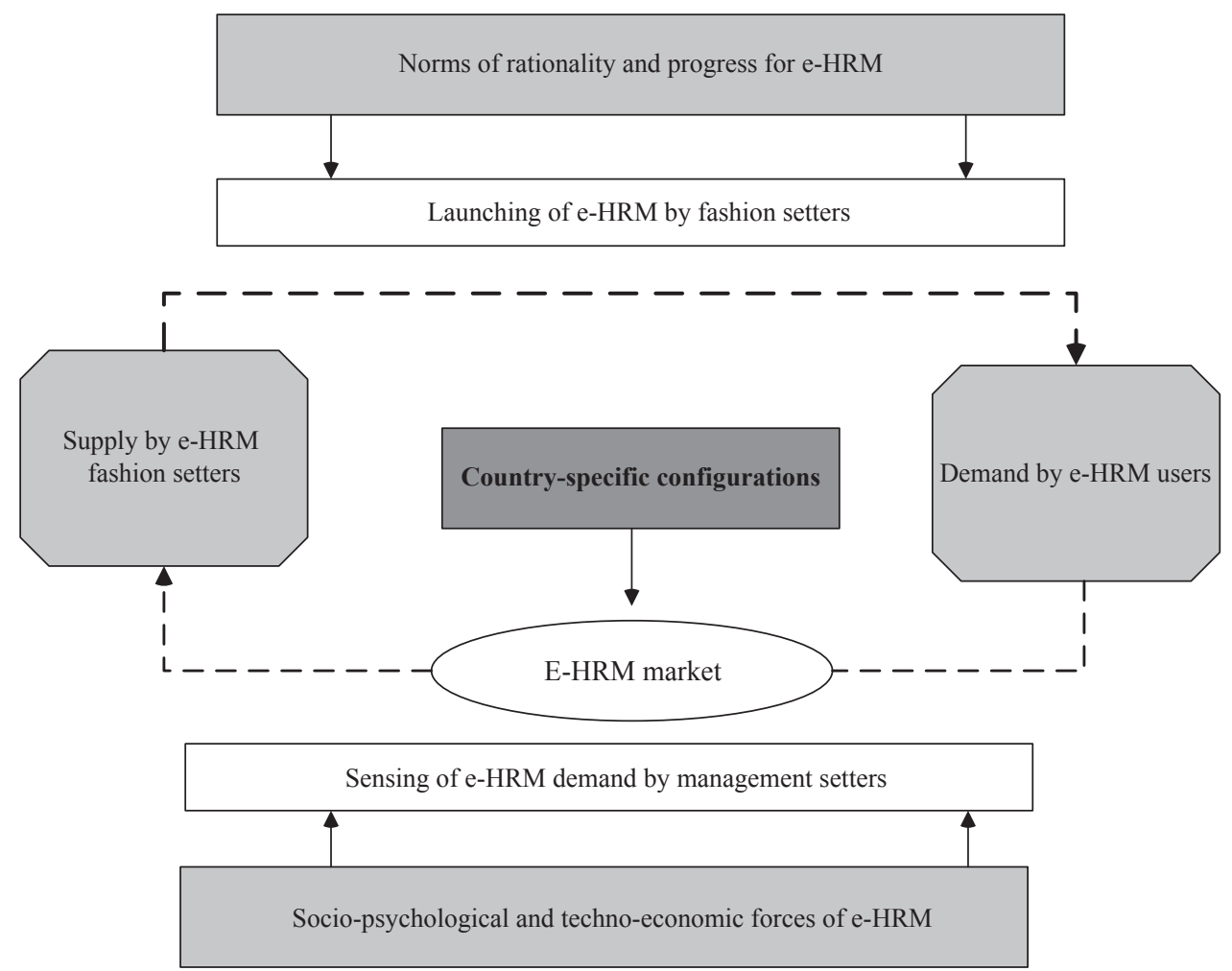

Figure 16.1 Management fashion-setting process for e-HRM 
Table 16.3 E-HRM adoption case studies - management fashion perspective

\begin{tabular}{|c|c|c|c|}
\hline Publication & Case description & Socio-psychological forces & Techno-economic forces \\
\hline $\begin{array}{l}\text { Olivas-Lujan, } \\
\text { Ramirez and } \\
\text { Zapata-Cantu } \\
\text { (2007) }\end{array}$ & $\begin{array}{l}\text { Four case studies in Mexico, } \\
\text { deliberately chosen; they } \\
\text { needed to have a strong } \\
\text { reputation regarding } \\
\text { their 'traditional' HRM } \\
\text { practices. They come from } \\
\text { different industrial sectors } \\
\text { (manufacturing, consumer } \\
\text { and business products, and } \\
\text { service industries for both } \\
\text { businesses and consumers) }\end{array}$ & $\begin{array}{l}\text { Local idiosyncrasies in } \\
\text { developing countries, } \\
\text { cultural influences (respect } \\
\text { for authority, or a 'digital } \\
\text { gap' between generations), } \\
\text { managerial support, } \\
\text { employee mindsets and } \\
\text { educational levels }\end{array}$ & $\begin{array}{l}\text { Industry (banks feel more } \\
\text { pressure to adopt e-HRM, } \\
\text { because ICT is a key factor } \\
\text { for delivering competitive } \\
\text { products), country's } \\
\text { geography and infrastructure }\end{array}$ \\
\hline $\begin{array}{l}\text { Bondarouk, } \\
\text { Schilling and } \\
\text { Ruël (2016) }\end{array}$ & $\begin{array}{l}\text { Eleven case studies in MNC } \\
\text { subsidiaries in Indonesia } \\
\text { implementing e-HRM, from } \\
\text { different sectors and varying } \\
\text { in size, globally and locally }\end{array}$ & $\begin{array}{l}\text { HQ influence and 'traditional' } \\
\text { management support }\end{array}$ & $\begin{array}{l}\text { Available resources, business } \\
\text { environment, government } \\
\text { regulations }\end{array}$ \\
\hline $\begin{array}{l}\text { Ruël, Bondarouk } \\
\text { and Looise } \\
\text { (2004) }\end{array}$ & $\begin{array}{l}\text { Five case studies implementing } \\
\text { e-HRM among large } \\
\text { companies (> 15,000 } \\
\text { employees) with long } \\
\text { experience and a good } \\
\text { reputation with e-HRM }\end{array}$ & $\begin{array}{l}\text { Mindset and behaviour of } \\
\text { employees, line managers } \\
\text { and HR personnel, IT skills of } \\
\text { employees }\end{array}$ & $\begin{array}{l}\text { Shift in power in employment } \\
\text { relationship, globalisation, } \\
\text { cultural and language } \\
\text { differences, political factors, } \\
\text { company size }\end{array}$ \\
\hline $\begin{array}{l}\text { Burbach and Royle } \\
\qquad(2010)\end{array}$ & $\begin{array}{l}\text { A single US MNC case study, } \\
\text { and a few of its subsidiaries } \\
\text { in Germany and Ireland into } \\
\text { diffusion of e-HRM practices } \\
\text { in the subsidiary }\end{array}$ & Organisational culture & $\begin{array}{l}\text { Strength of national business } \\
\text { system, micro-political } \\
\text { relationship between HQ } \\
\text { and subsidiaries, institutional } \\
\text { differences between } \\
\text { home and host countries, } \\
\text { organisational structure }\end{array}$ \\
\hline $\begin{array}{l}\text { Comacchio and } \\
\text { Scapolan } \\
(2004)\end{array}$ & $\begin{array}{l}\text { Twenty Two case studies in the } \\
\text { banking sector in Italy into } \\
\text { the adoption of e-learning } \\
\text { solutions. The researchers } \\
\text { questioned if this process } \\
\text { was driven by rational } \\
\text { arguments (economic } \\
\text { benefits), or by emotional } \\
\text { arguments (the fear of } \\
\text { losing legitimacy or strategic } \\
\text { advantage compared to } \\
\text { competitors) }\end{array}$ & - & Pressure from competitors \\
\hline Hooi (2006) & $\begin{array}{l}\text { Case studies in Malaysia } \\
\text { aimed at understanding the } \\
\text { extent to which e-HRM was } \\
\text { practised in SMEs in the } \\
\text { manufacturing industry, and } \\
\text { to explore the readiness and } \\
\text { feasibility of implementing } \\
\text { e-HRM within those SMEs }\end{array}$ & $\begin{array}{l}\text { Organisational culture, } \\
\text { managerial support, } \\
\text { attitudes of employees, } \\
\text { availability of expertise, } \\
\text { learning capabilities and } \\
\text { commitment of employees }\end{array}$ & $\begin{array}{l}\text { Rapidly growing SMEs, the } \\
\text { presence of subsidiaries } \\
\text { (made it more cost effective } \\
\text { to have one HRM system), } \\
\text { availability of resources } \\
\text { and technical infrastructure, } \\
\text { government support }\end{array}$ \\
\hline $\begin{array}{c}\text { Bondarouk and } \\
\text { Ruël (2013) }\end{array}$ & $\begin{array}{l}\text { The single case study } \\
\text { investigated the strategic } \\
\text { benefits of e-HRM in a } \\
\text { large federal governmental } \\
\text { organisation in Belgium }\end{array}$ & - & Globalisation \\
\hline
\end{tabular}


Table 16.3 (Continued)

\begin{tabular}{|c|c|c|c|}
\hline Publication & Case description & Socio-psychological forces & Techno-economic forces \\
\hline $\begin{array}{l}\text { Hustad and } \\
\text { Munkvold } \\
(2005)\end{array}$ & $\begin{array}{l}\text { The single case study of a global } \\
\text { Swedish telecommunications } \\
\text { company explored the } \\
\text { implementation project of an } \\
\text { e-competence management } \\
\text { system }\end{array}$ & $\begin{array}{l}\text { Organisational culture, } \\
\text { commitment of employees }\end{array}$ & $\begin{array}{l}\text { Tension between global } \\
\text { standardisation and local } \\
\text { needs (cultural differences } \\
\text { in, for example, labour law } \\
\text { and work policies) }\end{array}$ \\
\hline $\begin{array}{l}\text { Martin and } \\
\text { Reddington } \\
(2010)\end{array}$ & $\begin{array}{l}\text { The researchers developed a } \\
\text { model of e-HRM, focusing on } \\
\text { the relationship between HR } \\
\text { strategy, e-HRM goals and } \\
\text { architectures, and positive } \\
\text { and negative outcomes, } \\
\text { and studied it in a major } \\
\text { international company with } \\
\text { around } 64,000 \text { employees in } \\
80 \text { countries }\end{array}$ & $\begin{array}{l}\text { Levels of technology acceptance } \\
\text { among employees and line } \\
\text { managers }\end{array}$ & $\begin{array}{l}\text { Resources and absorptive } \\
\text { capacity of HR function }\end{array}$ \\
\hline Ruta (2005) & $\begin{array}{l}\text { This study assessed HRM } \\
\text { portal implementation in } \\
\text { subsidiaries of Hewlett } \\
\text { Packard studying the } \\
\text { implementation of its @HP } \\
\text { Employee Portal in its Italian } \\
\text { subsidiary }\end{array}$ & $\begin{array}{l}\text { Individual reactions of } \\
\text { employees towards using } \\
\text { IT technology, managerial } \\
\text { attitude towards change, } \\
\text { professionalism }\end{array}$ & $\begin{array}{l}\text { Organisation size (large, global } \\
\text { organisations implement } \\
\text { IT applications), national } \\
\text { contextual issues, industry } \\
\text { characteristics, resources }\end{array}$ \\
\hline Wiblen (2016) & $\begin{array}{l}\text { This case study of a large } \\
\text { professional service firm in } \\
\text { Australia aimed to build } \\
\text { a frame of usefulness } \\
\text { of e-HRM in talent } \\
\text { management }\end{array}$ & $\begin{array}{l}\text { Perceived usefulness of e-HRM } \\
\text { by stakeholders }\end{array}$ & \\
\hline $\begin{array}{l}\text { Schalk, } \\
\text { Timmerman } \\
\text { and Van den } \\
\text { Heuvel (2013) }\end{array}$ & $\begin{array}{l}\text { Three case studies in Dutch } \\
\text { semi-profit organisations } \\
\text { aimed at exploring how } \\
\text { strategic considerations } \\
\text { influence the decision- } \\
\text { making on e-HRM } \\
\text { applications }\end{array}$ & $\begin{array}{l}\text { Interpersonal communication } \\
\text { with other e-HRM adopters }\end{array}$ & \\
\hline
\end{tabular}

\section{REFLECTION ON MANAGEMENT FASHION THEORY IN E-HRM}

\section{Norms of Rationality and Progress}

The most important drivers in the management fashion-setting process in Figure 16.1 are the norms of rationality and progress, and the socio-psychological and technoeconomic forces. These drivers shape the demand and supply of e-HRM and do influence the decision-making within organisations regarding the implementation of new
e-HRM systems. As such, they will be discussed first in the text below. Norms of rationality and progress are defined as societal-forced expectations that managers have to use management techniques believed to be new, improved and the most efficient. They determine whether or not a manager is interested in a particular management technique - in this case e-HRM. The academic literature was reviewed to identify examples of these norms. In the case of rationality, the focus lay on the effectiveness of e-HRM, while the progressiveness of e-HRM was 
evaluated based on factors that determined the innovativeness of the management technique.

In a case study of 10 different organisations, Parry and Tyson (2011) suggested that e-HRM brought a certain value to organisations. They analysed organisations from UK industries that had implemented e-HRM a year or more prior to the study. These organisations were in different systems and stages of e-HRM implementation. The results showed that e-HRM was introduced to improve efficiency, service delivery, standardisation and organisational image, to empower managers and to transform HRM into a strategic function. The results (Parry \& Tyson, 2011) showed that efficiency, service delivery and the standardisation goals were often realised and there was also some evidence of transformational impact in that HRM staff had more time and information to support the organisation's business strategy. This meant that e-HRM increased efficiency and effectiveness. However, the realisation of these norms depended also on the design and implementation of e-HRM systems, and also may depend on the appropriate redeployment skilling of HRM staff (Parry \& Tyson, 2011). What is missing in their study is the individual user as a unit of analysis. Parry and Tyson only studied the impact of e-HRM at an organisational level. Ruël and van der Kaap (2012) addressed this issue in a literature review on the benefits of e-HRM. Here, they also included the user-level determinants of e-HRM value creation. They assumed firms invested in e-HRM to create value, and they produced a table summarising the benefits of e-HRM that categorised levels of effectiveness, efficiency and service (Ruël \& Van der Kaap, 2012). Examples of efficiency benefits of e-HRM were cost reduction (Lawler, 2005), increased quality and pace of the HRM function (Biesalki, 2003), time savings from e-communications (Ramirez \& Cantu, 2008), increased profitability, market share and size (Foster, 2009) and increased administrative efficiency (Heikkila, 2010; Marler \&
Fisher, 2013). Benefits at a service level were, for example, faster information exchange (Holm, 2010), data accessibility and availability (Holm, 2010), higher quality services (Maatman, Bondarouk, \& Looise, 2010), decreased information errors and improved service delivery (Bondarouk \& Ruël, 2009; Lawler, 2005).

Of course, there are more case study research studies that identified factors that influenced the decision to adopt and implement e-HRM within organisations. For example, Comacchio and Scapolan (2004) argued that, based on articles and consultant's reports on e-learning, e-HRM can have two main advantages: namely, the gain of flexibility and economies of scale. Olivas et al. (2007) found that an e-HRM strategy helped to achieve cost-effectiveness for one of the firms in their case studies, and argued that firms cannot afford to suffer the disadvantages of traditional, labour-intensive HR tasks in a globally competitive marketplace. Ruël et al. (2004) mentioned that e-HRM was an innovation in terms of HRM. It created opportunities to put employee-management relationships into the hands of employees and line managers, and IT helped in designing HRM tools and instruments more easily. Ruël et al. (2004) also argued that, especially in terms of operational and information processing work, there was less demand for HR people. For more strategic roles (such as management and organisation development), HR staff (and the accompanying experience) would still be necessary. Martin and Reddington (2010) argued that e-HRM had the potential to result in a radically changed, or even virtualised, HR function. Furthermore, it could reduce HR transaction costs and HR headcount. This would make the sharing of information easier and more flexible, and facilitate more effective virtual 'customer relationships' and internal labour markets (Martin \& Reddington, 2010).

Further, Hustad and Munkvold (2005), who studied an IT-supported competence system in use at Ericsson, argued that this 
system had a large potential to improve the efficiency and effectiveness of competence management in the organisation. Also, gaining global access to the competence resources of the company could also increase innovativeness and stimulate new learning processes (Hustad \& Munkvold, 2005). Ruta (2005) studied the worldwide implementation of the HP Employee Portal at Hewlett Packard. This portal was designed to increase the speed and ease of access to internal communications and corporate information in order to increase effectiveness and the production capacity of employees (Ruta, 2005). The goal of HP was to reduce IT and HR operating costs and to increase integration among the different business units. Two years after the launch, the HR department in Italy (for example) saved 15\% of the costs on average.

Wiblen (2016) argued that e-HRM can enhance efficient and effective management of human resources, standardise and harmonise the HR function. This resulted in faster and more accurate decisions, and provided stakeholders with access to data about talent. She studied a professional service firm in Australia, and found the implementation of e-HRM systems were perceived as useful (compared to older Human Resource Information Systems) and cost effective. The ability of employees was measured more easily and the system helped to make sure that the organisation could categorise employees based on performance and potential. Furthermore, e-HRM could standardise the meaning of talent (based on boundaries of required skills and capabilities, making it objectively measurable), improve the consistency between business units and make sure that talent identification processes were integrated and strategically aligned (Wiblen, 2016).

Finally, e-HRM can result in unintended benefits, such as an improved image of the HRM department, the professionalisation of HR specialists, greater transparency, and a more objective measuring of employee performance (Bondarouk \& Ruël, 2013). E-HRM is also associated with a positive image of the organisation among (potential) employees, a greater autonomy of employees and new roles within the HRM function (Schalk et al., 2013).

To conclude, according to the academic literature e-HRM as a management technique is rational and progressive or, at least, has the potential to be. Some examples of these norms include time saving, increased profitability, fewer errors, higher quality services and the reduction of administration costs. According to the academic research, e-HRM is (or has the potential to be, depending on the context) efficient as well as progressive (new compared to older techniques), and can help to achieve HRM goals.

\section{Socio-psychological and Techno-economic Forces}

The research model has shown that sociopsychological and techno-economic forces shape the demand of (potential) e-HRM users. Socio-psychological forces are based on people's desires and psychological states, while techno-economic forces are based on, for example, macro-economic fluctuations, politics and contradictions within organisations. The academic literature in general and, specifically, the literature that uses case studies as a methodology were analysed again (secondary data analysis) to find out which socio-psychological and techno-economic forces (contextual factors) played a role in adopting and implementing e-HRM.

Voermans and Van Veldhoven (2007) conducted research at Philips Electronics in the Netherlands and studied the attitude of employees towards e-HRM systems. Their research is based partly on the technology acceptance model (TAM), a framework published by Davis (1989). This framework assumes that the perceived usefulness and ease of use of a technology together shape the attitude towards the use of this technology. Also, the preferred role HR has to play within an organisation, according to 
employees, determines the attitude towards e-HRM (Voermans \& Van Veldhoven, 2007). Voermans and Van Veldhoven also found that (logically) positive experiences with an IT system (especially its usability) and the employees' preference as to the role played by HR in the organisation (especially the strategic preference) improve the attitude towards e-HRM, and make it easier to implement e-HRM. Generally, e-HRM is more valued by managers who prefer a more strategic role for the HRM function. Also, user support is very important for managers because it creates a more positive attitude towards e-HRM (Voermans \& Van Veldhoven, 2007). Technological, organisational and human factors all appear to be equally important and mutually influence each other during implementation (Voermans \& Van Veldhoven, 2007). Yusliza and Ramayah (2012) conducted a comparable study in Malaysia, as this part of the world has not been researched in the area, unlike Europe and the USA. These authors found similar results: user satisfaction, the clarity of e-HRM goals, perceived usefulness, perceived ease of use, social influence, user support and facilitating conditions all had a positive influence on using e-HRM (Yusliza \& Ramayah, 2012).

At the macro-level, for example, organisational size, computer experience of the firm, the (duration of) existence of an HRIS department, the nationality of the firm, multicultural context and national culture all played a role (Ruël \& Van der Kaap, 2012). Olivas-Lujan et al. (2007) argued that, especially in developing countries, organisations have to take local idiosyncrasies into account. Ramirez and Cantu (2008) also added organisational culture to this list.

Other researchers found further determinants of e-HRM adoption and implementation. For example, Strohmeier and Kabst (2009) found that, next to organisational size, the configuration of HRM plays an important role. As discussed earlier, Madsen and Slatten (2013), as well as Benders and van Bijsterveld (2000), argued that countryspecific configurations are important in the diffusion of management fashions. This has been confirmed for e-HRM by a few authors mentioned in Table 16.3. The adoption and implementation of e-HRM was influenced by a country's geography, infrastructure, government regulations, local idiosyncrasies, culture, business environment, political factors, government support and micro-political relationships between home and host countries (Bondarouk et al., 2016; Burbach \& Royle, 2010; Hooi, 2006; Marler \& Fischer, 2013; Olivas-Lujan et al., 2007; Panayotopoulou et al., 2010; Ramirez \& Cantu, 2008; Ruel et al., 2004). So, as each country/culture is different, the process of e-HRM adoption and implementation is reasoned differently given different national contexts.

Table 16.4 gives an overview of the sociopsychological and techno-economic forces influencing the adoption and implementation of e-HRM.

The findings above allowed us to refine and unfold the management fashion concept for the adoption of e-HRM (Figure 16.2).

\section{DISCUSSION}

How can we interpret the research model, displayed in Figure 16.2? After analysing the academic e-HRM literature, a clear set of interesting findings emerged. E-HRM is progressive, as well as rational, and the studies published show a substantial set of socio-psychological and techno-economic forces. Beyond being progressive (innovative), e-HRM also has the capability to gain performance benefits for organisations. Technological advancements have made IT evermore powerful, accessible and interesting for large firms, as well as for medium-sized or even smaller and micro-firms, according to Olivas-Lujan et al. (2007). The findings of their study of 2007 would be even more applicable today. There is insufficient empirical evidence as yet to conclude univocally that e-HRM leads to actual economic advantages. Also, it is not easy to measure the 
Table 16.4 An overview of socio-psychological and techno-economic forces in e-HRM from case studies

\begin{tabular}{ll}
\hline Socio-psychological forces & Techno-economic forces \\
\hline - Local idiosyncrasies (especially in devel- & - Industry (e.g. banks feel more pressure to adopt e-HRM \\
oping countries) and HQ influence & because ICT is a key factor in delivering competitive \\
- Cultural influences (e.g. respect for & products) \\
$\begin{array}{ll}\text { authority, or a 'digital gap' between } & \text { - Country's geography and infrastructure } \\
\text { generations) } & \text { - Available resources } \\
\text { - Managerial support } & \text { - Business environment (which is different in developing } \\
\text { - Employee mindsets and educational } & \text { economies, compared to emerging economies) } \\
\text { - levels } & \text { - Government regulations } \\
\text { - Employee (computer) skills } & \text { - Organisation size (SMEs, in general, have more difficulties } \\
\text { - National culture } & \text { implementing e-HRM) } \\
\text { - 'Traditional' management support } & \text { - Environmental infrastructure } \\
\text { - User acceptance, HR skills, leadership } & \text { - employees) } \\
\text { - Availability of expertise } & \text { - Globalisation, cultural and language differences } \\
\text { - Learning capabilities } & \text { - Data access } \\
\text { - Commitment of employees } & \text { - Security and privacy } \\
\text { - Internal communication } & \text { - Project management traditions } \\
& \text { - Pressure from competitors } \\
& \text { - Firm performance }\end{array}$ \\
\hline
\end{tabular}

benefits of e-HRM, especially when there are 'soft' factors present, such as talent management and e-learning. In these cases, sometimes the results are of an intangible nature. Of course, the competencies and skills of employees can be measured, but it is difficult to draw conclusions from this because it is difficult to study the impact of e-HRM in 'isolation'; organisation contextual factors do interfere with the adoption and usage of e-HRM and, therefore, may have helped to improve employee performance. Furthermore, the evaluation process is time consuming and expensive. E-HRM is also a progressive management technique as it is quite different from older techniques. Computers are taking over the roles normally executed by employees working in the HR department of an organisation. Finally, there were a lot of different factors (socio-psychological and techno-economic) influencing the adoption and implementation of e-HRM within organisations. It is difficult to analyse the management fashion-setting process from the supply side, as management fashion setters are difficult to define from case studies, and the dissemination of rhetoric is difficult to measure. As stated earlier, some parts of the model cannot be explained by analysing case studies alone. We acknowledge that it will be very time consuming to analyse the whole process as displayed in Figure 16.2. Furthermore, some parts of the model are difficult to measure, for example the role of management fashion setters. The case studies reviewed showed no clear evidence that consultancy firms, social media, conference organisers, business media or management gurus play an important role in the implementation and adoption process of e-HRM systems within firms. It is impossible to name all the fashion setters responsible for the diffusion of e-HRM, as there is much 'hidden' information that cannot be measured well. And not all rhetoric regarding the diffusion of e-HRM in organisations is documented well. Also, to understand if the decision to adopt and implement an e-HRM system within an organisation is based on the rhetoric from management fashion setters, extra interviews with the managers responsible for the adoption and implementations of these systems would be 


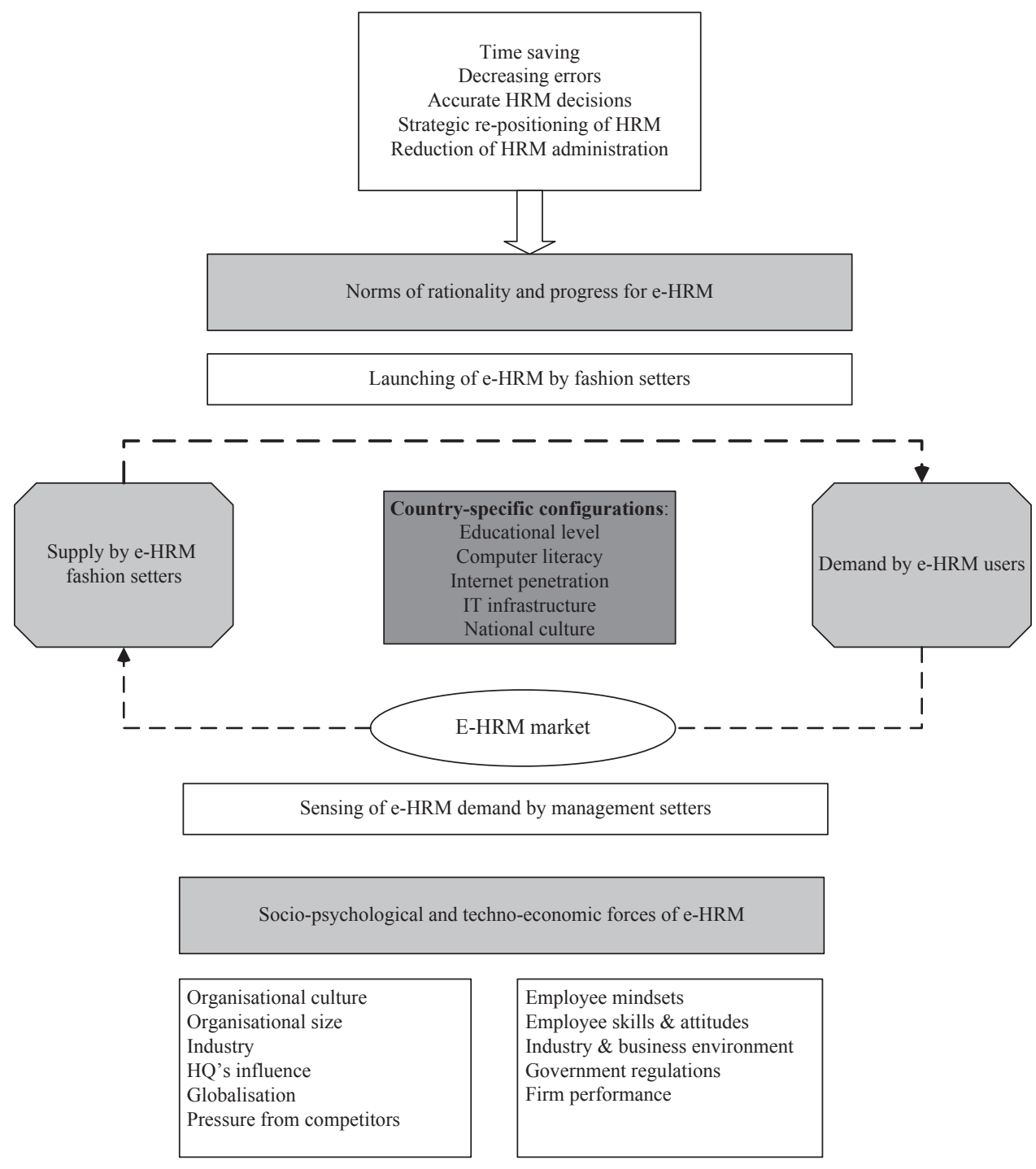

Figure 16.2 Refined model for e-HRM management fashion

necessary. This is not only to get an understanding of the emotions that played a role in the decision-making process, but also to get a good overview of the reasoning and arguments the decisions were based on. Governments are also influencers in the process of adopting and/or implementing an e-HRM system, especially for SMEs.

Hooi (2006) argued that government could play a role in the adoption and implementation of e-HRM, especially in SMEs. For example, it can encourage these firms to take part in conferences, but it also has an influence on organisations by means of government regulations and policies. This indicates that a government can be an influencer, but possibly not a fashion setter, because it does not have a direct interest in selling e-HRM to organisations. Employees, line management and, particularly, top management 
do play a role in 'selling' e-HRM within organisations. The current case study analysis showed that, next to fashion setters such as consultancy firms, professional media and business schools (which originate from outside of the organisation), actors from within organisations also can play a role in shaping management fashion (particularly in 'selling' e-HRM to employees). These actors could consist of top managers deciding to implement e-HRM and trying to convince employees to use the e-HRM system, but also line managers could influence the decisionmaking regarding e-HRM applications within firms. The HR department itself could also promote its own ideas for e-HRM, for example to top management so as to influence the decision-making. In this case, they have to align their vision and strategies with the e-HRM architecture they propose to implement and the stakeholders' needs they wish to stress (Martin \& Reddington, 2010, p. 1570). To convince these stakeholders, they have to address a performance gap that can be solved by implementing e-HRM.

In their article, Ruël et al. (2004, p. 374) stated that only two of the five companies they studied had a clear HRM strategy that included a clear vision on, and linkage with, e-HRM, as well. The other three companies had an overall idea about where to go in the future, but the link between e-HRM and an HRM strategy was less clear. What is interesting here is that employees, line management and, particularly, top management did play a role in 'selling' e-HRM within the organisation. In one case, Ruël et al. argued, 'the cost reduction goal is more of a hope than a short term expectation, and perhaps a way of selling e-HRM plans to the top management'. Also, the HRM department at ABN AMRO Luxembourg started a marketing campaign to stimulate e-HRM use and this was quite successful (Ruël et al., 2004, p. 377).

Bondarouk and Ruël (2013) studied a governmental organisation in Belgium and found similar results. One of the HR specialists they interviewed mentioned that the HR director was a 'fantastic leader' and a driver of the change towards e-HRM (p. 400). Martin and Reddington (2010) argued that, for an effective e-HRM strategy, the HR department has to build and present a business case for e-HRM and promote its own ideas, to convince senior and line management and other stakeholders that e-HRM will have significant benefits. This was confirmed by Ruta (2005), who argued that managerial actions can help manage change and successful IT implementation. In his case, the CEO of HP personally and enthusiastically presented the implementation plan for e-HRM (and used norms of rationality and progress, indicating that the HR department would also be the recipient of significant benefits). The objective was to build awareness and excitement for the HP portal among employees. The top management built a whole communication plan here to influence/improve acceptance among employees, and asked them to use it for performance benefits (Ruta, 2005).

Wiblen (2016), who investigated the use of e-HRM in talent management in a professional service firm, argued that an array of stakeholders, which included individual executives and business units, should engage in discursive activity to generate new meaning to help (or hinder) the enactment of talent management (Wiblen, 2016, p. 96). So, here, empirical evidence is offered that indicates stakeholders within a professional service firm determined whether or not e-HRM was adopted for talent management purposes, based on quantitative measurement or through observations. Wiblen described the process of adopting e-HRM in this firm as an ongoing process of negotiation, whereby measuring and observing approaches, as well as divergent interpretations, were seen as legitimate. Furthermore, she wrote in her article that the discourses on e-HRM were influenced by the power and agency of senior executives and their opinions and approaches 
towards e-HRM in relationship with talent management, rather than just being based on the ability of the technology to realise performance benefits.

In conclusion, it seems that actors from outside the organisation can be management fashion setters (in this case e-HRM fashion setters), while actors from within organisations (particularly top management) can play this role also. In this case, the rhetoric to convince potential e-HRM users does not come from outside the organisations, but from within them. The rhetoric around e-HRM has been mostly based on rational arguments, for example performance benefits, business cases and clear objectives (Schalk et al., 2013), and to a lesser extent on emotionally charged and unreasoned arguments. However, this was not always the case. The research on e-learning in Italy by Comacchio and Scapolan (2004) showed that, in the Italian context, the decision process was far from being rational. Organisations often already have an ERP or HRIS system in place before deciding to implement an updated e-HRM system. Schalk et al. (2013, p. 90) argued that the existence of HRIS technology in the organisation was a more important trigger for using e-HRM than were specific HR deliverables and business drivers. The main reason for adopting e-HRM was to add extra infrastructure. Organisations could feel under pressure when other organisations had already adopted e-HRM, or when the use of web-based applications in daily life created a need for organisations to implement e-HRM applications (Schalk et al., 2013).

This is the first time that e-HRM has been approached systematically by using a research model based on management fashion theory. This chapter gives an extensive overview of what has been written on using management fashion theory so far. It has also provided an analysis of the different contributions of researchers from other fields to management fashion theory and their scientific contributions to the theory. Since e-HRM is a popular and upcoming management technique nowadays, it has been exceptionally valuable to investigate this through the lens of management fashion, especially to determine which factors have influenced the adoption and implementation processes of e-HRM within organisations. What has becomes clear from this is the fact that e-HRM certainly does have some characteristics of management fashion, but there are also a few black boxes that have not been uncovered at the moment. The supply side especially needs further investigation. Management fashion theory does not explain whether e-HRM as a phenomenon is here to stay or to disappear in the future. The lifecycle discourse theory of Abrahamson and Fairchild (1999) in Figure 16.1 tries to give a theoretical explanation for this. However, it is always unclear where a fashion is located at any one particular moment in time and how to determine exactly in which phase it is. This is particularly so when this is based only on the number of articles that are indexed. Also, management fashion theory does not explain how and when a fashion transforms into being routine. This makes it more difficult to determine whether an innovation in management is a fashion when it is unclear where the dividing line between a fashion and a routine is to be located. As a result, it is difficult to determine to what extent a certain management innovation (in this case e-HRM) is to be correctly called a management fashion. The theory shows only how a certain fashion is brought into the arena, not what happens after that or as a result.

For different types of organisations, no matter what sector they are in, this chapter could be very valuable, especially in improving their understanding of the factors influencing their decision-making processes in regard the adoption and implementation of e-HRM. This overview has provided a description of the internal and external factors influencing these processes. Also, it has tried to provide a context in which organisations can be made aware of the conflicting interests that play a role within these processes. Management 
fashion setters (e.g. consultancy firms, or business media) do have other interests compared to the interests of the organisations themselves. Management fashion setters' interest is to sell management techniques and earn money from this, while organisations are interested in improving their businesses. Although this is beyond the scope of this research, it would be very valuable for organisations to know which fashion setters they can trust and to what extent a fashion improves their business. In general, this chapter has tried to help organisations to become aware of their environment as an influencer within their decision-making, rather than just being a 'given' entity.

\section{CONCLUSION}

The aim of this study was to contribute to e-HRM research, as well as to management fashion research, by investigating e-HRM through a management fashion lens. The goal was to figure out to what extent e-HRM could be considered a management fashion and whether it has any clear rationale and is progressive. We applied Abrahamson's (1996) theory of management fashion to e-HRM as a management technique and analysed empirical studies on e-HRM.

First, it is important to note that, since management fashion theory is a meta-level theory, any management innovation will always tend to have 'symptoms' of a management fashion to a certain extent. This research is the first to analyse e-HRM from a management fashion theory perspective. Marler et al. (2016) has already studied HR analytics from the supply side. They investigated what role mass media had played in the diffusion process of HR analytics in a US context. The current research has investigated the demand side of the management fashion-setting process in particular, by investigating the factors that played a role in the adoption and implementation of
e-HRM within organisations. The case studies analysed were executed in many different organisations and within different national contexts, both in developing countries and in developed countries.

Second, we concluded that e-HRM could be considered as rational and progressive. According to management fashion theory, these are two conditions that a management technique has to meet in order to be considered for adoption by organisations. Also, this research has contributed to the understanding of those factors which played a role in the adoption and implementation process of e-HRM. These factors are called sociopsychological and techno-economic forces. The results from the case studies are displayed in Table 16.4. Furthermore, evidence was found that country-specific configurations and local idiosyncrasies do play an important role, influencing the demand of e-HRM by organisations. Evidence was also found in the case studies that forces from outside the organisation and internal controls have played a role in the adoption and implementation of e-HRM. The systems already in place and other operational constraints determined whether or not an organisation decided to adopt a new e-HRM system. Also, it could be the case that line managers, employees and, particularly, top management played a significant role in 'selling' the new system within the organisation. So, clearly, e-HRM shows real characteristics of being a management fashion.

Although e-HRM certainly has some characteristics of such a fashion, there are some 'black boxes' too. For example, no evidence could be found for the supply side of the management fashion-setting process. The 'sensing of e-HRM demand by fashion setters' and 'launching of e-HRM by fashion setters' could not be measured given the e-HRM studies analysed. More research is needed to draw conclusions on this particular side of the management fashion-setting process. Some information will be almost impossible to obtain, given all the rhetoric 
used by management fashion setters for 'selling' e-HRM and naming all those responsible for the diffusion of e-HRM. What could be measured is where the managers responsible for the adoption of e-HRM get their information. It would be interesting to find out what persuaded them to adopt certain e-HRM systems, which fashion setters played a role in this and what rhetoric they used to make their explicit demands for e-HRM applications. In this way, step by step, we would expect that the management fashion-setting process for e-HRM could become more evident. However, completing the whole model for e-HRM in the future will likely prove very difficult.

\section{REFERENCES}

Abrahamson, E. (1991). Managerial fads and fashion: The diffusion and rejection of innovations. Academy of Management Review, 16, 586-612.

Abrahamson, E. (1996). Management fashion. Academy of Management Review, 21(1), 254-285.

Abrahamson, E., \& Fairchild, G. (1999). Management fashion: Lifecycles, triggers, and collective learning processes. Administrative Science Quarterly, 44(4), 708-740.

Abrahamson, E., \& Fombrun, C. (1994). Macroculture: Determinants and consequences. Academy of Management Review, 19, 728-755.

Benders, J., \& Van Bijsterveld, M. (2000). Leaning on lean: The reception of a management fashion in Germany. New Technology, Work and Employment, 15(1), 50-64.

Benders, J., \& Van Veen, K. (2001). What's in a fashion? Interpretative viability and management fashions. Organization, 8(1), 33-53.

Biesalski, E. (2003). Knowledge Management and e-Human Resource Management. Karlsruhe: DaimlerChrysler.

Bondarouk, T., Parry, E., \& Furtmueller, E. (2017). Electronic HRM: Four decades of research on adoption and consequences.
International Journal of Human Resource Management, 28(1), 98-131.

Bondarouk, T., \& Ruël, H. (2009). Electronic human resource management: Challenges in the digital era. International Journal of Human Resource Management, 20, 505-514.

Bondarouk, T., \& Ruël, H. (2013). The strategic value of e-HRM: results from an exploratory study in a governmental organization. The International Journal of Human Resource Management, 24(2), 391-414.

Bondarouk, T., Schilling, D., \& Ruël, H. (2016). eHRM adoption in emerging economies: The case of subsidiaries of multinational corporations in Indonesia. Canadian Journal of Administrative Sciences/Revue Canadienne des Sciences de l'Administration, 33(2), 124-137.

Burbach, R., \& Royle, T. (2010). Global integration versus local adaption of an e-HRM system in a US MNC. Evidence-based review of E-HRM and strategic human resource management. Proceedings of the 3rd European Academic Workshop on Electronic Human Resource Management, Bamberg, 289-306.

Clark, T. (2004). Strategy viewed from a management fashion perspective. European Management Review, 1(1), 105-111.

Comacchio, A., \& Scapolan, A. (2004). The adoption process of corporate e-learning in Italy. Education + Training, 46(6/7), 315-325.

Davis, F. D. (1989). Perceived usefulness, perceived ease of use, and user acceptance of information technologies. MIS Quarterly, 13(3), 319-340.

Fincham, R., \& Roslender, R. (2004). Rethinking the dissemination of management fashion: Accounting for intellectual capital in UK case firms. Management Learning, 35(3), 321-336.

Foster, S. (2009). Making Sense of e-HRM: Technological frames, value creation and competitive advantage. Hatfield: University of Hertfordshire.

Grant, D., Dery, K., Hall, R., Wailes, N., \& Wiblen, S. (2009). Human resource information systems (HRIS): An unrealised potential. Presented at the Chartered Institute of Personnel and Development. Nottingham, 1-20. 
Grant, K. (2011). Knowledge management, An enduring but confusing fashion. Electronic Journal of Knowledge Management, 9(2), 117-131.

Heikkila, J. (2010). A Delphi study on e-HRM: Future directions. Proceedings of the 3rd European academic Workshop on Electronic Human Resource Management, Bamberg, 229-249.

Hendrickson, A. R. (2003). Human resource information systems: Backbone technology of contemporary human resources. Journal of Labor Research, 24(3), 382-394.

Holm, A. (2010). The effect of e-recruitment on the recruitment process: Evidence from case studies of three Danish MNCs. Proceedings of the 3rd European Academic Workshop on Electronic Human Resource Management, Bamberg, 91-111.

Hooi, L. W. (2006). Implementing e-HRM: The readiness of small and medium sized manufacturing companies in Malaysia. Asia Pacific Business Review, 12(4), 465-485.

Hustad, E., \& Munkvold, B. E. (2005). IT-supported competence management: A case study at Ericsson. Information Systems Management, 22(2), 78-88.

lles, P., Chuai, X., \& Preece, D. (2010). Talent management and HRM in multinational companies in Beijing: Definitions, differences and drivers. Journal of World Business, 45(2), 179-189.

Lawler, E. (2005). From human resource management to organizational effectiveness. Human Resource Management, 44(2), 165-169.

Maatman, M., Bondarouk, T., \& Looise, J. K. (2010). Conceptualizing the capabilities and value creation of HRM shared service models. Human Resource Management Review, 20(4), 327-339.

Madsen, D., \& Slåtten, K. (2013). The role of the management fashion arena in the crossnational diffusion of management concepts: The case of the balanced scorecard in the Scandinavian countries. Administrative Sciences, 3(3), 110-142.

Madsen, D. Ø., \& Slåtten, K. (2015). Social media and management fashions. Cogent Business \& Management, 2(1), 1-17.

Marler, J., Cronemberger, F., \& Tao, C. (2016). HR analytics: Here to stay or short lived management fashion? in Electronic HRM in the Smart Era. Bingley: Emerald, pp. 59-85.

Marler, J., \& Fisher, S. (2013). An evidencebased review of e-HRM and strategic human resource management. Human Resource Management Review, 23(1), 18-36.

Martin, G., \& Reddington, M. (2010). Theorizing the links between e-HR and strategic HRM: A model, case illustration and reflections. International Journal of Human Resource Management, 21(10), 1553-1574.

Martin, G., Reddington, M., \& Alexander, H. (2008). Technology, Outsourcing and Transforming HR. Amsterdam: Elsevier.

Nijholt, J. J., \& Benders, J. (2007). Coevolution in management fashions: The case of self-managing teams in The Netherlands. Group \& Organization Management, 32(6), 628-652.

Olivas-Lujan, M. R., Ramirez, J., \& ZapataCantu, L. (2007). e-HRM in Mexico: Adapting innovations for global competitiveness. International Journal of Manpower, 28(5), 418-434.

Ortmann, G. (1995). Formen der Produktion; Organisation and Rekursivität. Opladen: Westdeutscher Verlag.

Parry, E., \& Tyson, S. (2011). Desired goals and actual outcomes of e-HRM. Human Resource Management Journal, 3, 335-354.

Ramirez, J., \& Cantu, L. (2008). E-HR adoption by firms in Mexico: An exploratory study. Rio's International Journal on Sciences of Industrial and Systems Engineering and Management, 2, 44-73.

Ruël, H., Bondarouk, T., \& Looise, J. K. (2004). E-HRM: Innovation or irritation. An explorative empirical study in five large companies on web-based HRM. Management revue, January, 364-380.

Ruël, H., \& van der Kaap, H. (2012). E-HRM usage and value creation: Does a facilitating context matter? German Journal of Human Resource Management: Zeitschrift für Personalforschung, 26(3), 260-281.

Ruta, C. D. (2005). The application of change management theory to HR portal implementation in subsidiaries of multinational corporations. Human Resource Management, 44(1), 35-53.

Schalk, R., Timmerman, V., \& Van den Heuvel, S. (2013). How strategic considerations influence 
decision making on e-HRM applications. Human Resource Management Review, 23(1), 84-92.

Schuler, R. S., Jackson, S. E., \& Tarique, I. (2011). Global talent management and global talent challenges: Strategic opportunities for IHRM. Journal of World Business, 46(4), 506-516.

Staw, B. M., \& Epstein, L. D. (2000). What bandwagons bring: Effects of popular management techniques on corporate performance, reputation, and CEO pay. Administrative Science Quarterly, 45(3), 523-556.

Strohmeier, S. (2007). Research in e-HRM: Review and implications. Human Resource Management Review, 17(1), 19-37.

Strohmeier, S., \& Kabst, R. (2009). Organizational adoption of e-HRM in Europe: An empirical exploration of major adoption factors. Journal of Managerial Psychology, 24(6), 482-501.
Ten Bos, R. (2000). Fashion and Utopia in Management Thinking. Amsterdam: John Benjamins.

Voermans, M., \& Van Veldhoven, M. (2007). Attitude towards e-HRM: An empirical study at Philips. Personnel Review, 36, 887-902.

Wang, P. (2010). Chasing the hottest IT: Effects of information technology fashion on organizations. MIS Quarterly, 34(1), 63-85.

Wiblen, S. (2016). Framing the usefulness of eHRM in talent management: A case study of talent identification in a professional services firm. Canadian Journal of Administrative Sciences/Revue Canadienne des Sciences de l'Administration, 33(2), 95-107.

Yusliza, M. J., \& Ramayah, T. (2012). Determinants of attitude towards E-HRM: An empirical study among HR professionals. Procedia - Social and Behavioral Sciences, 57, 312-319. 